\title{
Ethereal Beauty in 3 Heritage Tengkolok of the Perak Sultanate
}

Salina Abdul Manan, Hamdzun Haron \& Zuliskandar Ramli

To Link this Article: http://dx.doi.org/10.6007/IJARBSS/v11-i11/11535 DOI:10.6007/IJARBSS/v11-i11/11535

Received: 04 September 2021, Revised: 11 October 2021, Accepted: 27 October 2021

Published Online: 22 November 2021

In-Text Citation: (Manan et al., 2021)

To Cite this Article: Manan, S. A., Haron, H., \& Ramli, Z. (2021). Ethereal Beauty in 3 Heritage Tengkolok of the Perak Sultanate. International Journal of Academic Research in Business and Social Sciences, 11(11), 21682181.

Copyright: (c) 2021 The Author(s)

Published by Human Resource Management Academic Research Society (www.hrmars.com)

This article is published under the Creative Commons Attribution (CC BY 4.0) license. Anyone may reproduce, distribute, translate and create derivative works of this article (for both commercial and non0-commercial purposes), subject to full attribution to the original publication and authors. The full terms of this license may be seen at: http://creativecommons.org/licences/by/4.0/legalcode

Vol. 11, No. 11, 2021, Pg. $2168-2181$

Full Terms \& Conditions of access and use can be found at http://hrmars.com/index.php/pages/detail/publication-ethics 


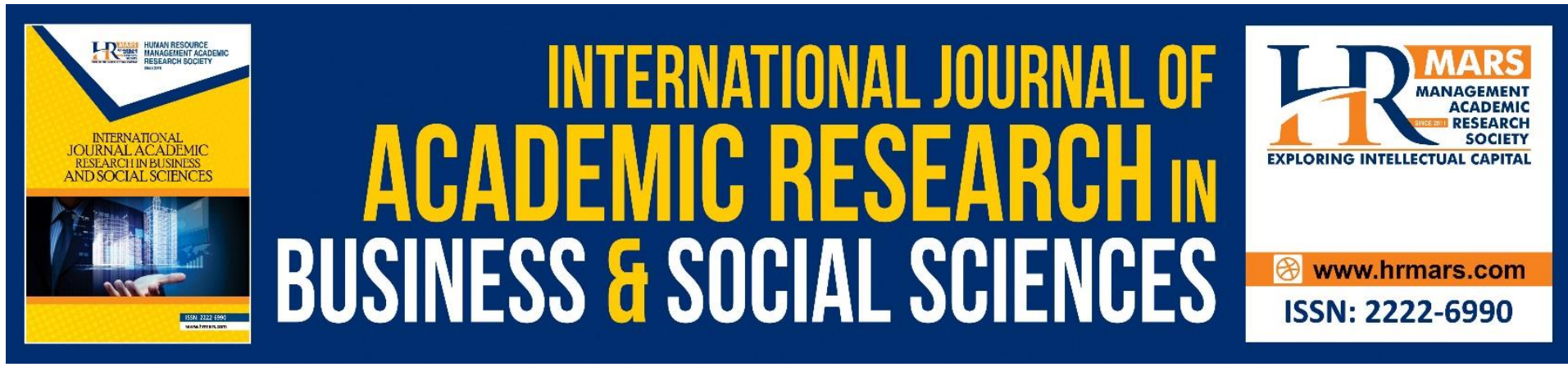

\title{
Ethereal Beauty in 3 Heritage Tengkolok of the Perak Sultanate
}

\author{
Salina Abdul Manan ${ }^{1}$, Hamdzun Haron² \& Zuliskandar Ramli ${ }^{1}$ \\ ${ }^{1}$ Institute of the Malay World and Civilization, Universiti Kebangsaan Malaysia (UKM), \\ Malaysia, ${ }^{2}$ School of Liberal Studies, Universiti Kebangsaan Malaysia (UKM), Malaysia. \\ Email: hh@ukm.edu.my
}

\begin{abstract}
Malays are well-known for their appealing and distinctive sartorial. A "tengkolok", or headdress, is the subject of reference. There are several terms for this headdress, such as tanjak, destars, setanjak or bulang ulu. The tengkolok is a Malay men's adornment and a symbol of their identity. It can be shaped in a variety of designs using only a piece of triangular-shaped fabric. Each of these designs is enhanced by its own folding and binding techniques to appeal captivating. Almost every state that adopts the monarchical system in Malaysia has its own distinctive tengkolok fashion. Although there is an equivalent name to the tengkolok, it however has different styles. Perak Darul Ridzuan, a state in Malaysia has its own tengkolok own design. Therefore, this paper aims to investigate on how the nature's pulchritude influences the design of the Perak state heritage tengkolok. The authors use a qualitative descriptive research method with a cultural approach to explain this. Data collection methods such as interviews and observations were used to collect written and visual data. According to the findings of the study, there are eight different designs of tengkolok in the Sultanate of Perak. These eight designs are divided into two categories: tengkolok designs that are still in use and tengkolok designs that are no longer in use. This paper will discuss the influence of nature in three tengkolok designs that are still in use today, namely Ayam Patah Kepak (APK), Helang Menyusur Angin (HMA) and Getang Pekasam (GP). Literature about the design of the tengkolok that is still in use can provide an opportunity for the younger generation to recognize the Malay cultural heritage, particularly the tengkolok in the Perak Sultanate. This literature also serves as an effort to appreciate and preserve the efforts of the Malay tengkolok artisans.
\end{abstract}

Keyword: Beauty, Design, Tengkolok, Perak Heritage

\section{Introduction}

Clothing is a tool or cultural art produced by humans as a daily necessity. Clothing is used for the purpose of protecting oneself from atmospheric conditions and conveys the value of decency as well as denotes symbolic meanings. Tengkolok is a part of the Malay men's attire that has existed since ancient times. Tengkolok is an adornment with a distinct design and meaning. Tengkolok is also worn as a head wrap by courtiers, dignitaries, and Malay grooms (Husain \& Malek, 1995). According to Abdul Jalil (2018), the tengkolok is also a head 
covering cloth or know as a decoration to hide the forehead. Each state in Peninsular Malaysia that adopts the monarchical system has its own tengkolok design. This tengkolok is known by a variety of names, including tanjak, setanjak, bulang hulu, sapu tangan, setangan, setangan kepala, semutar, destar and jastar (Aziz, 2006; Ismail, 1997). According to Mat (1982), the variety of names for this tengkolok is does not deviate from original meaning which is a kind of headdress. The term tengkolok is commonly used in literary texts tengkolok is a popular term in Perak, setanjak in Selangor, and destar in Negeri Sembilan (Ismail, 1997). The tengkolok's beautiful design is the result of a fabric binding technique that is created and improved based on one's status and refined to enhance its beauty over time (Ahmat, 2012).

\section{Research Objective}

- To describe the sultan of Perak and tengkolok fashioned design.

- To analyze the structure of the tengkolok design.

- To discuss the ethereal beauty in the heritage tengkolok of the Perak Sultanate

\section{Literature Review}

\section{Sultan of Perak and Tengkolok Fashioned Design}

The Perak Sultans and the design of the styled tengkolok were studied using photo sources from the National Archives, the National Museum, and the Office of His Majesty the Sultan of Perak (DYMM). According to the source, the Figures obtained are only from 10 Sultans, beginning with the 26th Sultan of Perak and ending with the 35th. According to Hashim, the collection in the Office of DYMM Paduka Seri Sultan of Perak only includes photographs of the Sultans of Perak from the 26th to the $35^{\text {th }}$ (Hashim, 2020, personal interview). This situation indicates that the tengkolok may not have been worn prior to the 26th Sultan of Perak because the Sultan's attire at the time was more influenced by the British ensemble. In the Perak Sultanate, the use and styling of tengkolok refers to the design that became the favorite and preferred of the ruling Sultan (Osman, 6 March 2014, personal interview). As a result, every Sultan who rules in the Sultanate of Perak has a favorite tengkolok design. Based on the photographs collected, the Sultan of Perak's reign can be divided into two periods: before and after the twentieth century. Prior to the 20th century, the Sultan of Perak ranged from the 26th Sultan of Perak to the 29th Sultan of Perak. After the 20th century, it was from the 30th Sultan of Perak to the present.

\section{Perak Sultans Prior to the 20th Century}

Before the twentieth century, the Sultans of Perak ruled from 1874 to 1918, from the 26th Sultan of Perak to the 29th Sultan of Perak. Referring to figure 1, 4 of the Sultan of Perak styled the wearing of songkok lipat and tarbus headdresses. Figure 1 (a) depicts the 26th Sultan of Perak, Sultan Abdullah Muhammad Shah II (Marhum Habibullah). He ruled the Sultanate of Perak for two years, from 1874 to 1876 (Harun, 2011). A close examination of the photograph revealed that he was not wearing a tengkolok as a headdress, but rather something resembling a songkok lipat.

Meanwhile, the 27th Sultan of Perak is Sultan Yusuf Sharifuddin Mudzafar Shah (Marhum Gharirullah). His Highness ruled the Sultanate of Perak for ten years, from 1886 to 1887 (Harun, 2011). Based on figure 1 (b), His Highness did not wear a tengkolok but rather a tarbus. The 28th and 29th Sultans of Perak came next. These two Sultans did not wear the tengkolok as headdresses either. The headdress worn in figure 1 ( $c$ and $d$ ) resembles a songkok that is matched with his official attire. Sultan Idris Murshidul 'Adzam Shah I (Marhum 
Rahmatullah) was the 28th Sultan of Perak. He ruled the Sultanate of Perak for twenty-nine years, from 1887 to 1916 (Harun, 2011). Sultan Abdul Jalil Karamatullah Shah (Marhum Radziallah), the 29th Sultan of Perak, ruled Perak from 1916 to 1918 (Harun, 2011).

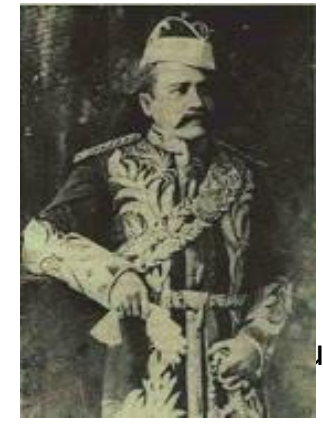

(a) SP ke-26

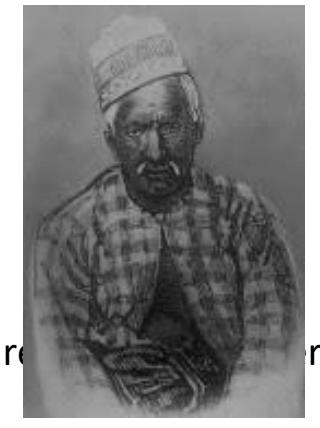

(b) SP ke-27

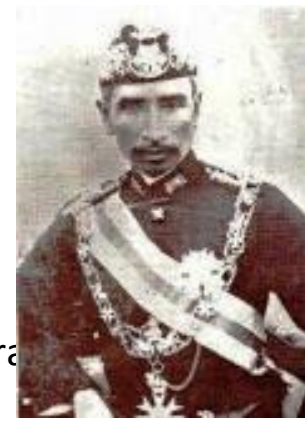

(c) SP ke-28

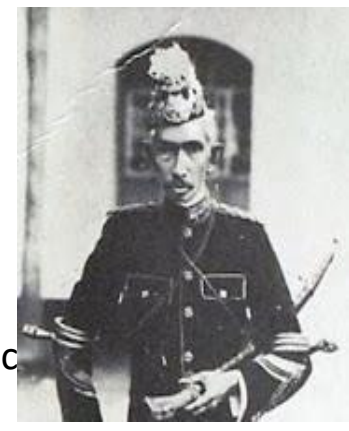

(d) SP ke-29

\section{Sultans of Perak After the 20th Century}

According to the source of the image collection examined, the wearing of the tengkolok has been prominent since the 30th Sultan of Perak, Sultan Iskandar (Marhum Kadasullah). From 1918 to 1938, he ruled Perak for two decades (Harun, 2011). According to figure 2 (e), His Highness wore the tengkolok and the Baju Melayu as his official attire. The tengkolok Alang Iskandar is a style of tengkolok that was worn during his reign. The collection of images discovered in the National Archives during his reign attests to this. Following that, the 31st Sultan of Perak, Sultan Abdul Aziz Almustasim Billah Shah (Marhum Ni'matullah), wore a tengkolok and the Baju Melayu, as shown in figure 2 (f). He ruled Perak for ten years, from 1938 to 1948 (Harun, 2011). His tengkolok is of the Alang Iskandar type, but it differs from the design of the 30th Sultan of Perak's tengkolok.

The 32nd Sultan of Perak is Sultan Yussuff Izzuddin Shah (Marhum Ghafaruallah). For fifteen years, he reigned from 1948 to 1963 (Harun, 2011). As shown in figure 2 (g), His Highness wore a headdress, specifically a tengkolok and a Baju Melayu as his official attire. The tengkolok worn is of the Alang Iskandar style, but it differs from that of the 30th and 31st Sultans. The 33rd Sultan of Perak wore the tengkolok as well as a Baju Melayu as his official attire, as shown in figure 2. (h). Sultan Idris Iskandar Al Mutawakil Allahahi Afifullah Shah II (Marhum Afifullah) ruled Perak for fifteen years, from 1963 to 1984 (Harun, 2011).

The 34th Sultan of Perak, Sultan Azlan Shah Muhibbuddin Shah, ruled Perak for thirty years from 1984 to 2014 (Harun, 2011). According to figure 2 (i), His Highness wore a tengkolok and Baju Melayu as his official attire. During his reign, the tengkolok was styled in the Ayam Patah Kepak style. Finally, the 35th Sultan of Perak, Sultan Nazrin Muizuddin Shah, who was inaugurated on May 6, 2015. He was seen following in the footsteps of his late father by wearing a tengkolok and the Baju Melayu. However, the design that he chose was of the Helang Menyusur Angin II (Abdul Manan, 2015) with an improved styling according to His Highness's order. 


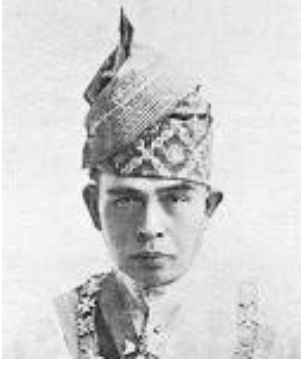

(e) SP ke-30

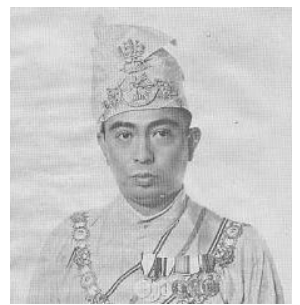

(h) SP ke-33

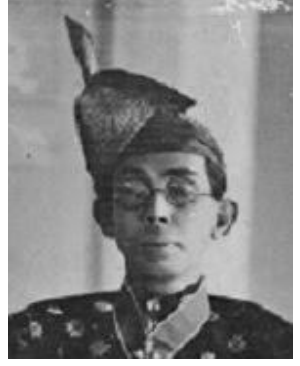

(f) SP ke-31

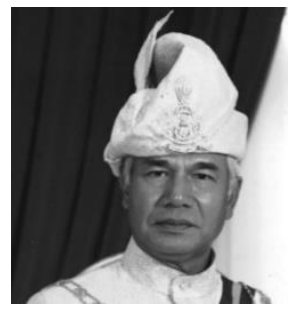

(i) SP ke-34

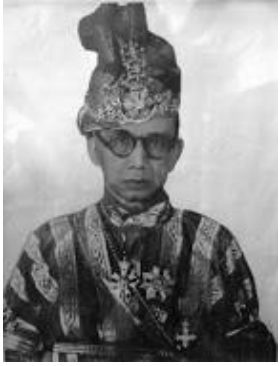

(g) SP ke-32

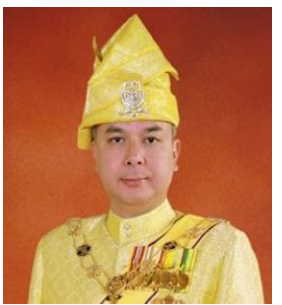

(j) SP ke-35

Figure 2: Sultans of Perak after the $20^{\text {th }}$ century

In conclusion, based on the 10 images examined, it is discovered that the wearing of the tengkolok by the Sultans of Perak has been popularized since 1918 and is still in use today. The Perak sultanate's use of the tengkolok conceals a mystery, who is the binder. As a result, the following section will discuss the people in charge of preserving the Perak sultanate's tengkolok, specifically the tengkolok artisan.

\section{The Royal Tengkolok Binder}

A Royal tengkolok binder is skilled in the processes of tengkolok fabric creation, tengkolok folding, and tengkolok beautification (Osman, 6 March 2014 and Raja Abdul Malek, 9 April 2020). This group is still active in Perak and has inherited the art of making tengkolok. Typically, they are a group with a connection to the palace, such as being descended from the Sultan of Perak or having served in the palace. However, according to Hashim (2014), no special post has been created in the palace for the tengkolok binder in the palace because the tengkolok binder refers to whoever is only interested in the art of tengkolok and Majesty's command only.

Abdul Manan (2015) lists four tengkolok binders found in the Sultanate of Perak, namely Toh Seri Wangsa Haji Abdul Rahim Mohamad, Yang Mulia (Y.M) Raja Azizulkhir Raja Harun AlRashid, Tuan Mohd Basri Ngah Mat Ali, and Tuan Mohd Dzulkarnain bin Osman, refer to the table 1. Toh Seri Wangsa Haji Abdul Rahim bin Mohamad and Tuan Mohamad Dzulkarnain bin Osman are both employees of Istana Iskandariah in Kuala Kangsar. Toh Seri Wangsa Haji Abdul Rahim bin Mohamad is also a royal wizard (Pawang diRaja). Meanwhile, Y.M Raja Azizulkhir Raja Harun Al Rashid is a former Commander at Istana Iskandariah, and Tuan Basri bin Ngah Mat Ali is a retired Perak Ministry of Culture staff member and the Manager of the Selandang Merah Group, SUK Perak. However, only Tuan Mohd Basri Ngah Mat Ali and Tuan Mohamad Dzulkarnain Osman were still active in the production of Perak tengkolok at the time (Abdul Manan, 2015). 
However, only two tengkolok binder are still active in the Sultanate of Perak until now, namely Tuan Haji Mohamad Dzulkarnain bin Osman and Y.M Raja Ahmad Akasha ibni Raja Abdul Malek. The three previous binders, namely the late Toh Seri Wangsa Haji Abdul Rahim Mohamad, the late Y.M Raja Azizulkhir Raja Harun Al-Rashid, and the late Tuan Mohd Basri Ngah Mat Ali are deceased (Osman, 6 March 2014 and Raja Abdul Malek, 9 April 2020). Y.M Raja Ahmad Akasha is the son of the late Y.M Raja Abdul Malek Ibni Al Marhum Raja Abd Rahman, the former InnervCommander of the Istana Iskandariah.

Table 1: Perak Sultanate Tengkolok Binder Year 2014

\begin{tabular}{ccll}
\hline No. & Binder & \multicolumn{1}{c}{ Name } & \multicolumn{1}{c}{ Title } \\
\hline 1. & $\begin{array}{c}\text { Tengkolok Binder 1 } \\
\text { (PB1) }\end{array}$ & $\begin{array}{l}\text { Toh Seri Wangsa Haji Abdul } \\
\text { Rahim bin Mohamad }\end{array}$ & Pak Tok Ibrahim \\
2. & $\begin{array}{c}\text { Tengkolok Binder 2 } \\
\text { (PB2) }\end{array}$ & $\begin{array}{l}\text { Y.M Raja Azizulkhir Raja Harun } \\
\text { Al Rashid }\end{array}$ & Ku Ayah or Ayah Jed \\
3. & $\begin{array}{c}\text { Tengkolok Binder 3 } \\
\text { (PB3) }\end{array}$ & $\begin{array}{l}\text { Tuan Mohd Basri Bin Ngah Mat } \\
\text { Ali }\end{array}$ & Haji Basnee \\
4. & Tengkolok Binder 4 & $\begin{array}{l}\text { Tuan Mohamad Dzulkarnain Bin } \\
\text { (PB4) }\end{array}$ & Paji Osman 'N' or Nain \\
& & & \\
\hline
\end{tabular}

Source: Salina, 2015

Table 2: Perak Sultanate Tengkolok Binder Year 2020

\begin{tabular}{ccll}
\hline No. & Binder & \multicolumn{1}{c}{ Name } & \multicolumn{1}{c}{ Title } \\
\hline 1. & Tengkolok Binder 1 & Tuan Haji Mohamad Dzulkarnain & Pak 'N' or Nain \\
& (PB1) & Bin Haji Osman & \\
2. & Tengkolok Binder 2 & $\begin{array}{l}\text { Y.M Raja Ahmad Akasha Y.M } \\
\text { (PB2) }\end{array}$ & Raja Abdul Malek \\
& Engku or Ku \\
\hline
\end{tabular}

Source: Field Work, 2020

Figure 3 depicts the traces of Perak sultanate's tengkolok from 2014 to the present. According to Osman (2014); (2020); Abdul Malek (2020), the Perak sultanate's original vocational lineage tengkolok binder is unknown. It is likely that the previous tengkolok binder did not inherit the vocation's original lineage. The main vocational that underpins this lineage is His Majesty Sultan Idris Iskandar, the 33rd Sultan of Perak, as depicted in this diagram. His Majesty the Sultan is also the only Sultan in Perak who knows how to tie and embellish the tengkolok. His Highness' knowledge and skills were passed down to Y.M Raja Norman Raja Harun Al Rashid, Y.M Raja Ismail Iskandar, and Toh Seri Wangsa Haji Abdul Rahim bin Mohamad.

Following that, Y.M Raja Ismail Iskandar passed on the skill of binding the tengkolok to Tuan Mohd Basir bin Ngah Mat Ali, also known as Haji Basnee. Meanwhile, Toh Seri Wangsa Haji Abdul Rahim bin Mohamad, also known as Pak Toh Ibrahim, passed on his knowledge to Tuan Haji Mohamad Dzulkarnain Osman, also known as Pak $\mathrm{N}$ or Nain. He also serves as His Majesty Sultan Nazrin Muizuddin Shah's tengkolok binder. Pak $\mathrm{N}$ has also studied and learned tengkolok binding skills from Y. M Raja Norman Raja Harun Al Rashid and Y.M Raja Azizulkhir King Harun Al Rashid. Meanwhile, Y.M Raja Mansur Raja Ahmad Darjis learned about tengkolok binding from Y.M Raja Azizulkhir Raja Harun Al Rashid. Finally, Y.M Raja Haji Abdul Malek ibni Al Marhum Raja Abdul Rahman and his son, Y.M Raja Ahmad Akasha Raja Abdul Malek, studied and learned tengkolok binding skills from Y.M Raja Norman Raja Harun Al Rashid, also known as Ku Ayah Norman. 


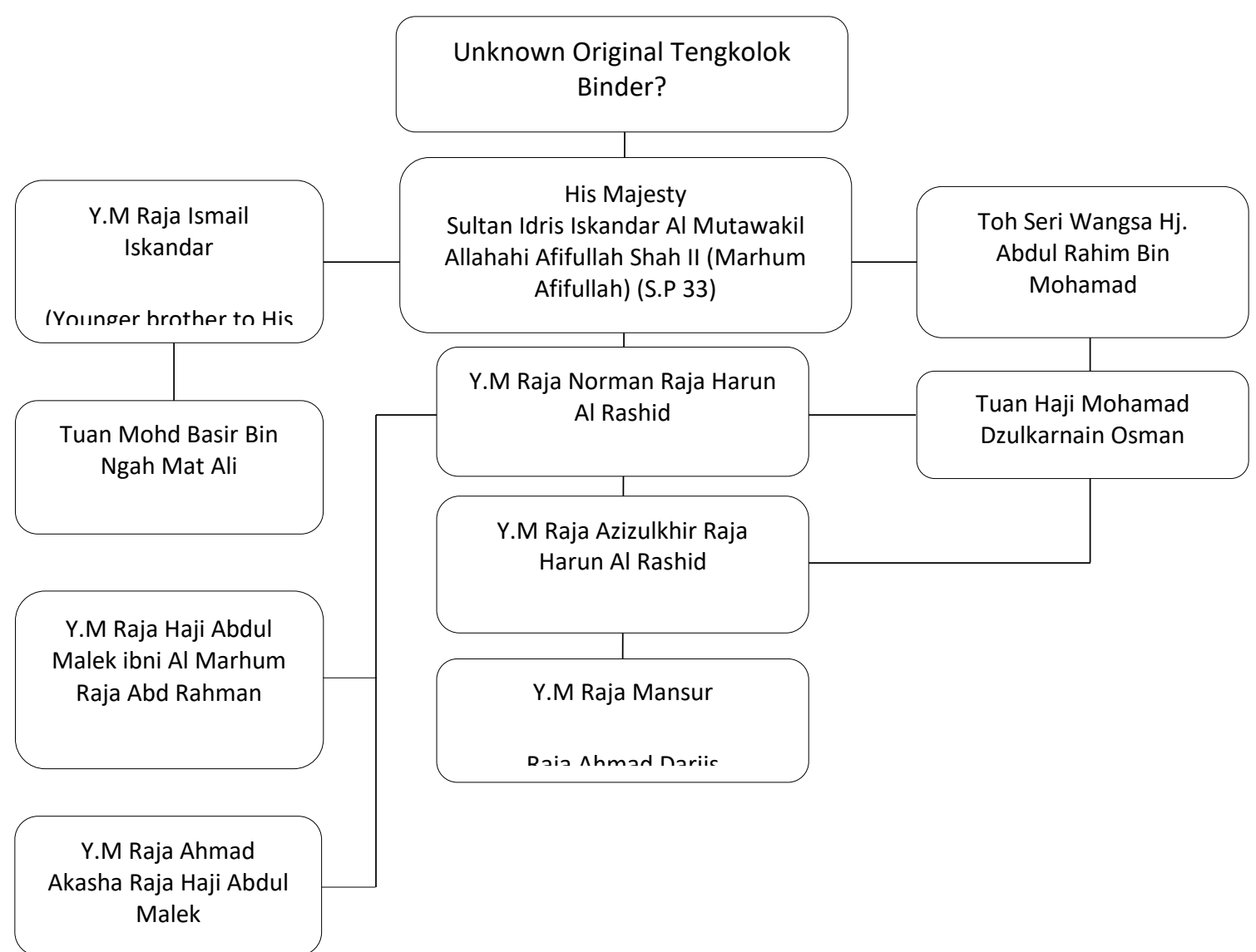

Figure 3: Vocational lineage of the Perak Sultanate's Tengkolok Binder Source: Field Work, 2020

\section{Research Methodology}

By conducting a literature review, visual analysis, and interviews, the qualitative method was used to analyze the pulchritudinous in the three designs of Perak Sultanate Heritage tengkolok. The primary data collected from several informants and writings on the Malay tengkolok were derived from interviews and observations. This key data is compared with a literature review to identify the artistry of nature in the designs of the tengkolok appraised.

\section{Findings and Discussion \\ Tengkolok Design Structure}

To discuss the design of the Perak sultanate's tengkolok, the main foundation that must be understood is the tengkolok's design structure. This structure explains the design division of the tengkolok as well as the parts involved in its formation. The design structure of the tengkolok to be discussed is related to the structural and functional theory. According to Durkheim (1986), functional-structuralism theory views society which is made up of various parts. This demonstrates how the Malays' lives are intertwined with nature in the production of unique handicrafts.

Everything the Malays produce or create has something to do with the world around them. Nature is one of the structures that relate to the Malay community's life and thus complete it. The same is true for the design of a tengkolok with specific structures or parts. To highlight the value of its beauty, a complete tengkolok design should have structures that 
are combined to form a strong tengkolok. The tapak, garam sebuku, pucuk rebong and solek are the structures that forms a tengkolok. In the design structure of the tengkolok, all these parts can be encapsulated into three main parts: the head, body, and feet.

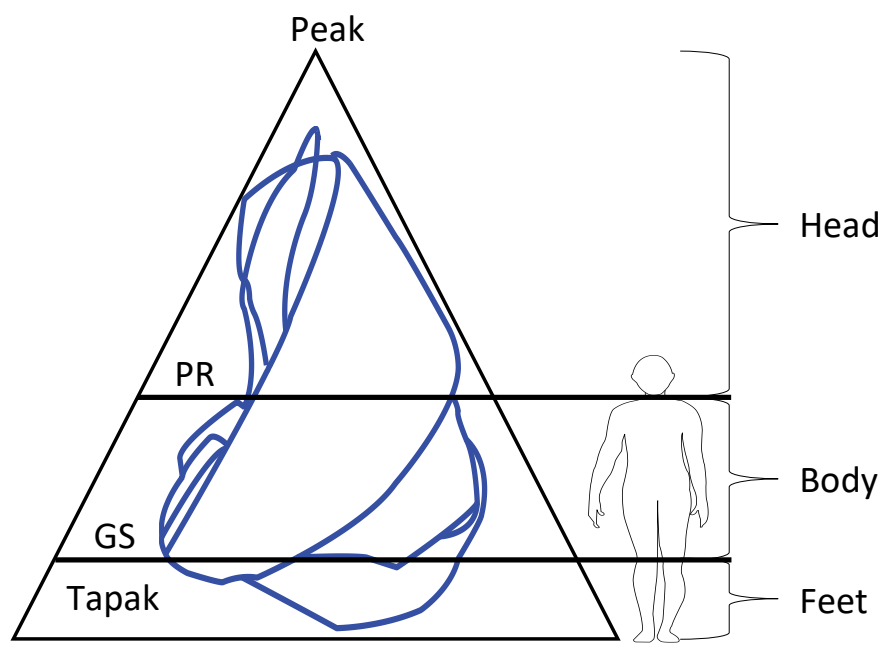

Figure 4: Structural Similarities of the Tengkolok Design with the human body Source: Salina, 2015

The tengkolok's design structure can also be divided into three major parts, as shown in Figure 4 above, namely the head, body, and feet. The peak is represented by the head, the body by garam sebuku, and the tapak by feet. The design structure of this tengkolok demonstrates that the tengkolok has parts that contribute to its formation. The tapak (base) section is the main structure inside a tengkolok. A tengkolok will be incomplete if the tapak, represented by the feet, is missing. In the formation of a tengkolok, the solek and garam sebuku, which are represented by the human body, are seen as the second structure. Garam sebuku represents the structure of the knot and thus helps to strengthen the tapak and solek.

As a result, the solek that will be formed is related to the structure of the tapak and the knot. Finally, there is the pucuk rebong structure, which represents the head which leads to the top of a tengkolok design. Thus, the Malays' craftsmanship is regarded as magnificent because they regard the tengkolok as an important adornment since it is worn on the head.

The tengkolok's design structure is similar to the traditional Malay house building structure, which is divided into three main parts, namely the head, body, and feet, as shown in figure 5 below. From a psychological standpoint, the traditional Malay house building form can be interpreted in two ways. The first interpretation is that the Malay house is divided into three sections that correspond to three important stages in life: birth, life, and death. The second interpretation is the human body, which includes the head, body, and feet (Nasir, 1985). As a result, the second interpretation in the construction of traditional Malay houses resembles the design structure of the tengkolok, which represents the head, body, and feet.

Furthermore, in the construction of traditional Malay houses, a triangular shape called tebar layar is located on the roof, as shown in figure 5. The purpose of this tebar layar is to provide adequate lighting and ventilation in the home. This triangular shape is also related to the tengkolok's design, which leads to the tengkolok's structure. The Malays are strongly associated with the triangular shape which is nature inspired. The forms of mountainous areas are the subject of discussion. 
This mountain shape has been a source of inspiration for Malays in creating works of art (Bujang \& Hamidon, 2002). The Malays create a variety of objects based on the shape of the mountains. These mountains or ridges' motifs are typically three parallel mountains. The mountain in the center is taller than the mountains to its right and left. Furthermore, the motif of this mountain is linked to Mount Meru, which is a Hindu-Buddhist belief. For example, during a wedding ceremony, a mountain could be placed behind the bridal dias. Another example is the wayang kulit (shadow play), which uses the mountains as a backdrop. In addition, an object in the mountain shape also serves as a currency. These mountain shapes are also used as mosquito nets, among other things (Bujang \& Hamidon, 2002).

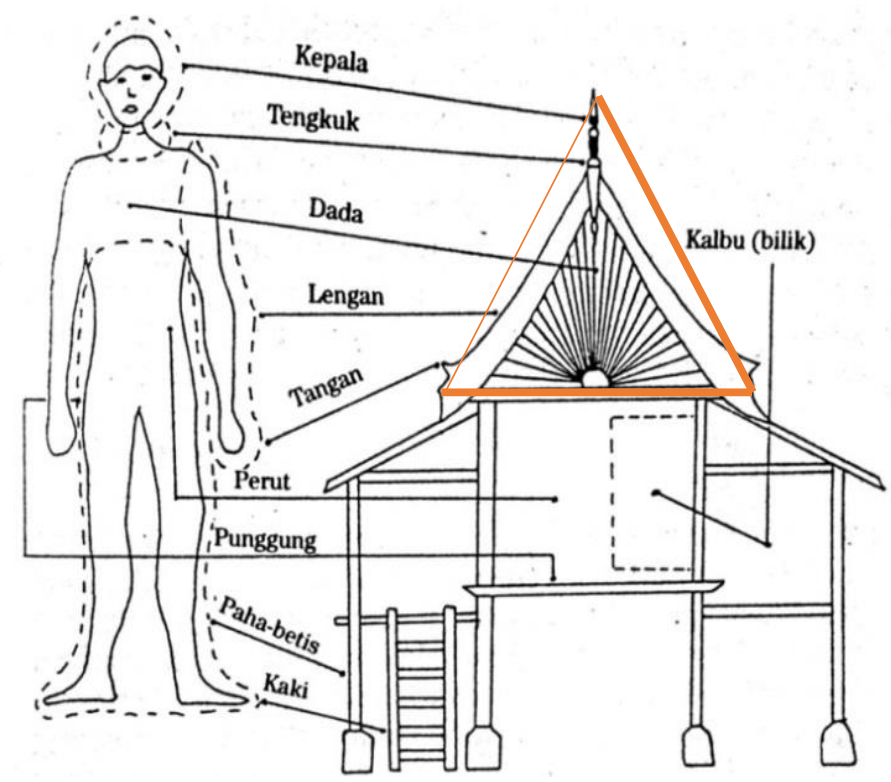

Figure 5: The Similarities of the Parts of The House with the limbs of human body Source: Abdul Halim, 1985

The status structure of the tengkolok is then formed based on the design structure of the tengkolok. The status structure of the tengkolok is also related to the triangular shape, which refers to the tiered symbol, as shown in figure 6. The tengkolok's status is divided into three categories: First Class (G1), Second Class (G2), and Third Class (G3) (G3).

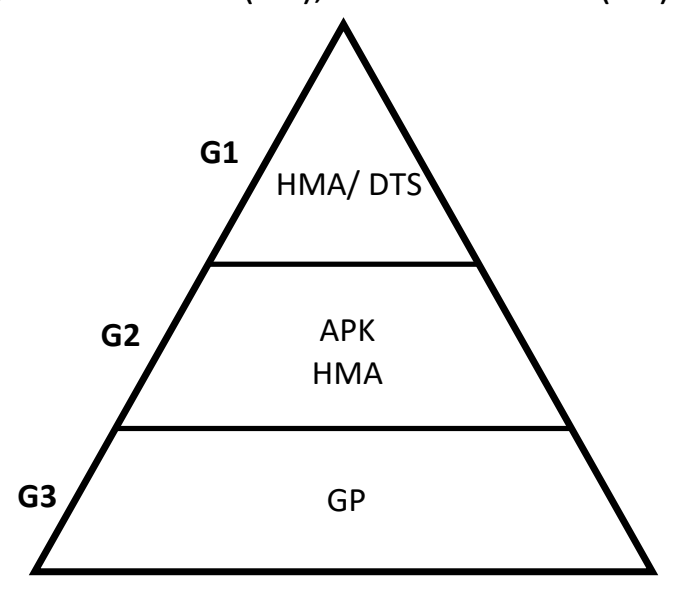

Figure 6 Structure of the status of the tengkolok and its bearer Source: Field Work, 2020 
The design of the tengkolok worn is related to the status structure. The Sultan is the FirstClass group status. He is the highest-ranking ruler in the sultanate hierarchy. As a result, the tengkolok worn is of the Helang Menyusur Angin (HMAll) style type (Abdul Manan, 2015). According to Osman (2014), the new enhancement of His Highness' tengkolok is based on what he approves through the changes he makes. Meanwhile, according to Raja Abdul Malek (2020), His Highness' design is known as Dendam Tak Sudah (DTS), and it is based on the DTS design styled by DYMM Sultan Yussuf Izzuddin Shah. This HMA or DTS has a higher pucuk rebong and a wider base than the tengkolok worn by a commoner. The pucuk rebong on the tengkolok of this First-Class status group is tall, even taller than the puncak solek. This height and width became a symbol of the sultan's sovereignty, as he ruled and wielded power. As a result, this measurement of height and width can only be known by the tengkolok binder in the palace because it is Perak sultanate confidentiality (Osman, 2014).

The tengkolok status structure for the second status group is Orang Besar. This second group consists of the Sultan's relatives and heirs who hold a position in the sultanate hierarchy. After a Sultan, they are the second most important group. As a result, the tengkolok used is of the Helang Menyusur Angin (HMA) and Ayam Patah Kepak (APK) variety. The design, however, differs from that of the first group's tengkolok, namely the Sultan. This difference can also be seen in the measurements of the pucuk rebong's height and the solek's width. This demonstrates that the tengkolok produced for the Second-Class group is inferior to the tengkolok produced for the First-Class group. Following that is the status structure of the Third-Class group tengkolok, which represents the Bentara, Jejawat, and Kalur. They are a group involved in the administration of official functions in the palace. The tengkolok worn is of the Getang Pekasam (GP) style. The design is lower and wraps around the entire head.

According to the study's findings, the design of the tengkolok in the Perak Sultanate is divided into two categories: the design that is used and the design that is not used. Helang Menyusur Angin, Ayam Patah Kepak, Dendam Tak Sudah, and Getang Pekasam are the designs used. Balong Ayam, Alang Iskandar, Anak Gajah Menyusu, and Pucuk Pisang Patah are the designs that are not used.

\section{Characteristics of the Perak State Tengkolok}

This study's tengkolok characteristics are an introduction to the Perak state tengkolok. Perak's Tengkolok is famous for its garam sebuku and pucuk rebong (Osman, 2014). As a result, Abdul Malek (2020) stated that the Perak tengkolok has a unique and distinct identity. The identity of the individual wearing a tengkolok with a pucuk rebong shows that the wearer is from a relative of the King of the Perak Sultanate (Abd Jalil, 2018).

Perak state tengkolok has two distinct characteristics: garam sebuku and pucuk rebong. These two characteristics distinguish Perak's tengkolok from other states' tengkolok, tanjak, or destar. This is due to the fact that the Perak state garam sebuku is a neatly made knot that produces pucuk rebong. The garam sebuku produced will be triangular in shape, while the pucuk rebong will be tapered. According to the basic folds made, both features of the Perak tengkolok will be produced neatly and beautifully. This is due to the fact that there are a few things to consider when performing a basic fold. Among them is that the size of the base fold that is made should be of the same size, straighten neatly, and the end of the base fold fabric should be tapered. However, there is a design of a tengkolok that has two pucuk rebong, namely Anak Gajah Menyusu as in figure 7 below. 


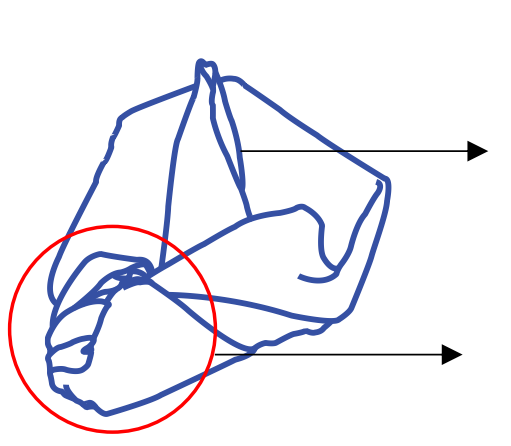

(a)

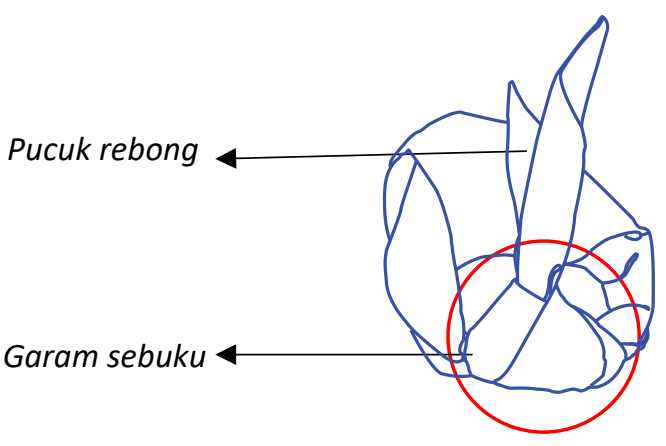

(b)

Figure 7: Sketch of the pucuk rebong and garam sebuku

(a) right view of the tengkolok Ayam Patah Kepak (b) back view of the tengkolok Anak Gajah Menyusu

\section{Ethereal Beauty in the Heritage Tengkolok of the Perak Sultanate}

The ethereal beauty found in the Perak tengkolok design is evident in the Ayam Patah Kepak (APK), Helang Menyusur Angin (HMA), and Getang Pekasam (GP) tengkolok designs. These three designs are still used during official palace ceremonies such as the Medal Awarding Ceremony, the Royal Funeral Ceremony, and the Sultan's Coronation Ceremony. Tengkolok APK and HMA are popular designs in the Perak Sultanate and are still worn on official occasions today. The GP's tengkolok is designed specifically for the kalur (the palace Nobat musician), the herald, and palace officials.

However, before His Majesty Sultan Azlan Shah Muhibbuddin Shah was installed as Sultan, the Orang Besar tengkolok was worn by the Getang Pekasam tengkolok, according to Osman (2020). During the reign of DYMM Sultan Azlan Shah Muhibbuddin Shah, however, His Majesty directed that Orang Besar style the tengkolok of Ayam Patah Kepak or Helang Menyusur Angin. This is due to His Majesty's love of beauty, and to ensure that the wearing of a tengkolok in the palace must be neatly styled. The wearing of the tengkolok designed by a Sultan of Perak is determined by the design preferred by His Majesty the Sultan of Perak (Osman, 2014).

In this regard, the tengkolok design used by His Majesty can also be used by ordinary people, with the permission granted by the late Sultan Azlan Shah Muhibbuddin Shah during his reign. Even though the designs worn by the Sultan and the common people are the same, they differ. The size of the tengkolok fabric measurements and the width of the base fold are where the difference lies.

The Perak state government keeps the size of His Majesty the Sultan's tengkolok a secret. The width of the basic fold indicates the rank of a Sultan who rules over the common people. His Majesty's tengkolok design cannot be folded without His Majesty the Sultan's permission or order. This is due to the fact that every attire worn by the Sultanate of Perak has a guardian from the supernatural realm, which is a Perak state government secret (Osman, 2014).

\section{(a) Tengkolok Ayam Patah Kepak (APK)}

The design of the Tengkolok Ayam Patah Kepak is a design favoured by Al Marhum DYMM Sultan Azlan Shah Muhibbuddin Shah. During His Majesty's reign, His Majesty adopted and styled the design of this APK tengkolok as the official tengkolok (Osman, 2014). The beauty of this tengkolok Ayam Patah Kepak's design is evident in its solek and inspiration. As 
shown in figure 8, the tengkolok APK has two broken parts. This tengkolok's two broken parts represent Ayam Patah Kepak (rooster with broken wings). The inspiration for the design of this tengkolok came from cockfighting, which was an old sport for the people. The previous tengkolok binder was inspired by the condition of a rooster that broke its wings during a cockfighting match.

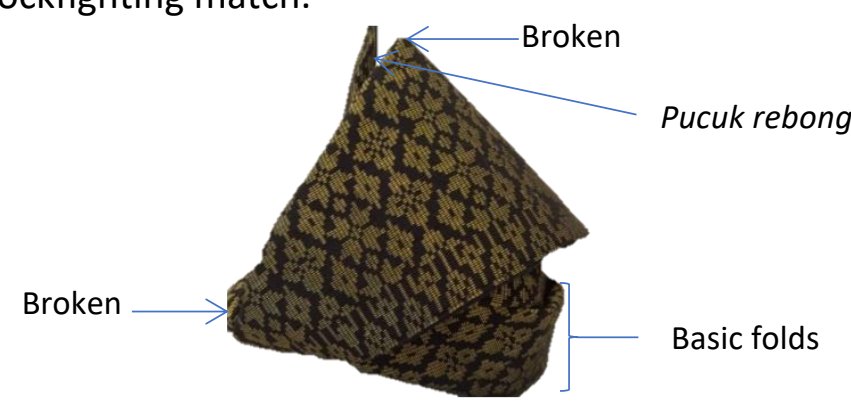

(a)

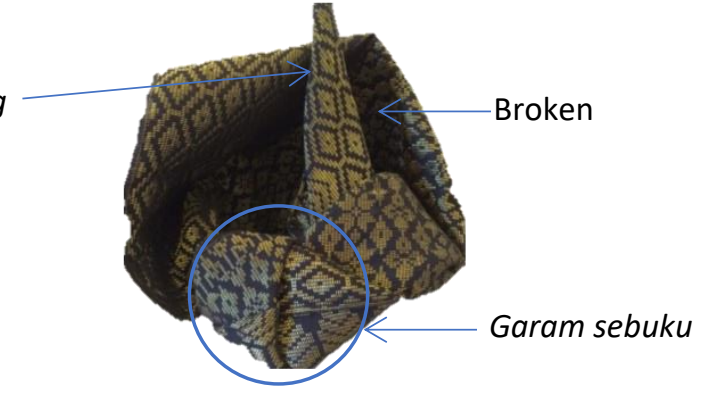

(b)

Figure 8: (a) Front view and (b) Side view

\section{(b) Tengkolok Helang Menyusur Angin (HMA)}

Tengkolok Helang Menyusur Angin is a popular tengkolok design in Perak due to its attractive design. The beauty of this HMA tengkolok design can be seen in the solek and inspiration that went into its creation. HMA solek has a curved part, as shown in figure 9 . The curved part of this tengkolok represents an "eagle gliding on the wind". The design of this tengkolok was inspired by an eagle flying high in the sky.

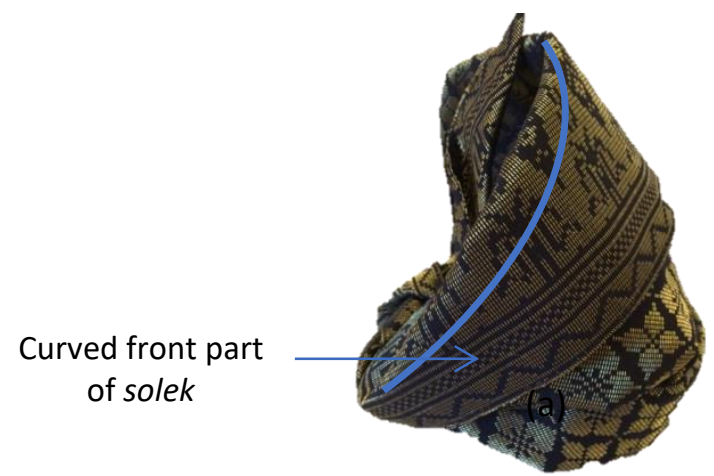

Figure 9: Front view (a) and Side view (b)

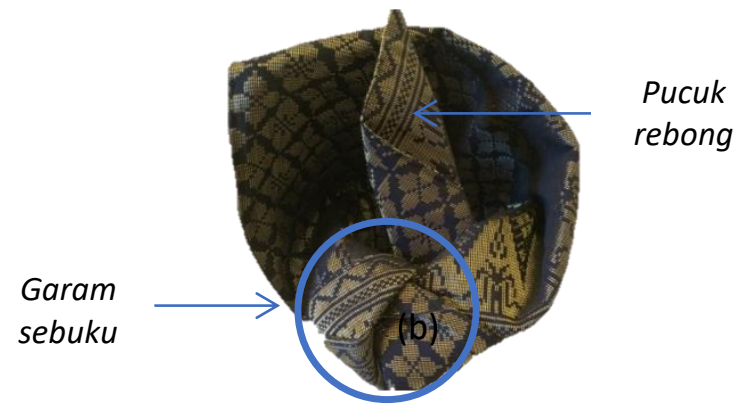

\section{(c) Tengkolok Getang Pekasam (GP)}

The name Getang Pekasam is a unique identification for this tengkolok design. The design of the tengkolok Getang Pekasam is inspired by one of the Perak Malay community's traditional foods, pickled fish. This design is inspired by the process of making pickled fish. This design has several spellings and pronunciations, including Getang Pekasam, Getam Pekasam, Ketang Pekasam, and Ketam Pekasam (Osman, 2014; Abd Jalil, 2019:2020; Abdul Malek, 2020). This difference in terminology is most likely due to how the tengkolok binder pronounced the name, which causes it to differ in written form. Even though the design of this GP tengkolok is known by various names, it has the same shape.

The Getang Pekasam tengkolok (GP) differs from other tengkolok designs in that it covers the entire head and has a triangular shape on the front. Figure 10 shows a dent in the middle of the top part of the tengkolok that covers the head. This part of the curve is a characteristic of 
the GP's tengkolok, which is neatly and orderly constructed (Akasha, 2020). However, there are a few tengkolok binders that make the middle section look like a flat surface, making this design look and unattractive when styled. During official ceremonies at the palace, kalur (the palace Nobat musician), herald, and palace officials wear this design. The design of this fully covered GP tengkolok is like other head covers worn by the Malay community when attending religious ceremonies, such as kopiah, turban, or songkok.

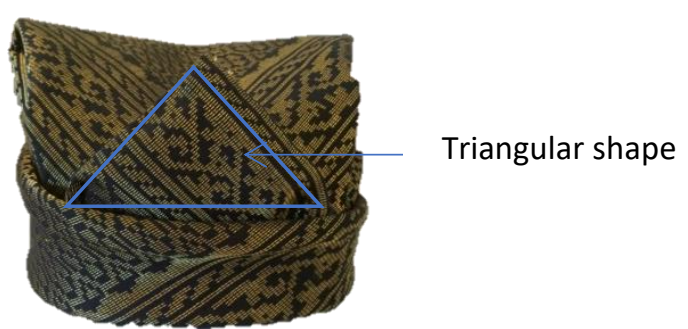

(a)

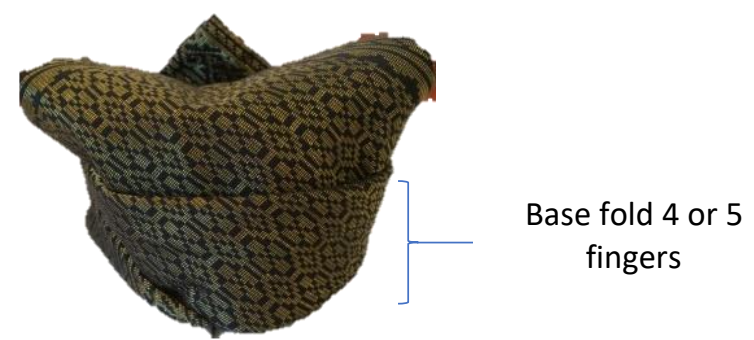

(b)

Figure 10: Front view (a) and Back view (b)

\section{Conclusion}

Tengkolok is one of the Malay Sultans' distinctive and beautiful headdresses. The invention that refers to the beauty of nature highlights the beauty of the Perak sultanate's tengkolok. This beauty served as the primary inspiration and for the previous society in creating the design of the tengkolok. This situation demonstrates how familiar the Malay community is with nature, such as fauna. The tengkolok's beauty has its own identity and significance. The identity and meaning thus define the Malays' creative and delicate art in conception and handicrafts. As a result, tying the tengkolok is one of the Malay community's skills that must be preserved and passed down. The art of tying the tengkolok is also a valuable Malay treasure. As a result, all parties must take responsibility for preserving the art of tengkolok binding. The younger generation is one of the target groups that should be prioritised in terms of acquiring these skills. This skill does not require only courtiers to learn it; what is important is that they are Malays who still appreciate their motherland and Malay heritage art. As a result, today's young generation is encouraged to learn the art of this skill so that it can be passed down from generation to generation.

\section{Corresponding Author}

Dr. Hamdzun Haron

School of Liberal Studies, Universiti Kebangsaan Malaysia, 43600 Bangi, Selangor

Email: hh@ukm.edu.my

\section{References}

Abd Jalil, M. A. (2020). The identity of the wearing a Tengkolok. Putrajaya. [Personal interview].

Abdul Jalil, M. H. (2018). Sejarah dan Martabat Tengkolok Dalam Etika Pemakaian Busana Kebudayaan Institusi Keistanaan Melayu Perak. Selangor: Perusahaan Tukang buku KM.

Abdul Manan, S. (2015). The Design Philosophy of Perak Sultanate [Unpublished Master's thesis]. Institute of the Malay World and Civilization, Universiti Kebangsaan Malaysia.

Ahmat, M. (2012). Siri Budaya Warisan Malaysia: Pakaian Tradisional. Kuala Lumpur: Pustaka Mawar 
Aziz, A. (2006). Rupa dan Gaya: Busana Melayu. Kuala Lumpur: Universiti Kebangsaan Malaysia

Bujang, R., \& Hamidon, N. A. (2002). Kesenian Melayu. Kuala Lumpur: Universiti Malaya.

Harun, J. (2011). Umpama Sebuah Bahtera Kajian Naskah Melayu Sejarah Kesultanan Negeri Perak. Kuala Lumpur: Arkib Negara Malaysia

Hashim, A. (2014). Sultan of Perak and Tengkolok. Istana Iskandariah Kuala Kangsar Perak. [Personal interview].

Husain, H., \& Malek, M. R. (1995). Pakaian dan Perhiasan Tradisional. Selangor: Prisma Sdn. Bhd.

Ismail, S. Z. (1997). Busana Melayu Johor. Johor: Yayasan Warisan Johor-Fajar Bakti.

Mat, R. (1982). Tengkolok: Research of Design and Symbol. [Unpublished bachelor's thesis]. Jabatan Persuratan Melayu, Universiti Kebangsaan Malaysia.

Nasir, A. H. (1985) Pengenalan Rumah Tradisional Melayu Semenanjung Malaysia. Kuala Lumpur: Loyal Press.

Osman, M. D. (2014). Styling of Tengkolok. Istana Iskandariah Kuala Kangsar Perak. [Personal interview].

Osman, M. D. (2020). Perak Sultanate Tengkolok Binder. Istana Iskandariah Kuala Kangsar Perak. [Personal interview].

Abdul Malek, R. A. A. (2020). Royal tengkolok binder. Ipoh Perak. [Personal interview]. 